\title{
Implementation of Lecturer's Professional Competency in Assessing Financial Performance
}

\author{
Agus Eko Sujianto \\ Institut Agama Islam Negeri Tulungagung, Indonesia \\ agusekosujianto@gmail.com
}

\begin{tabular}{ll}
\hline Article History & Received : July 9th 2021 \\
& Revision : August $17^{\text {th }} 2021$ \\
& Publication : Sept $30^{\text {th }} 2021$ \\
\hline
\end{tabular}

\begin{abstract}
This research is intended to implement the lecturer's professional competence, especially in assessing the performance of Puskesmas from the aspect of current ratio, efficiency ratio, and ROA. The research approach chosen is quantitative with descriptive research. The data collection technique uses documentation, namely financial reports published by Puskesmas "X" in 2016 and 2017. The results of the study explain that as a government institution managed using the BLUD mechanism, Puskesmas always pays attention to the management process for accounts as stipulated in public sector accounting that becomes an important part of assessing financial performance. Based on the current ratio, the ratio of total current assets and total current liabilities increased from 2016 to 2017 so that the performance of the Puskesmas was good. In the aspect of efficiency ratio, the comparison of expenditure realization and revenue realization of Puskesmas shows that puskesmas are efficient, especially in 2017. Puskesmas are also Quite Effective or Good Enough in generating ROA, so that in general this puskesmas works well, efficiently, and quite well in 2017.
\end{abstract}

Keywords: Lecturer's Professional Competence, Current Ratio, Efficiency Ratio, ROA

\section{INTRODUCTION}

Professional competence must be possessed by lecturers who are directed to realize the goals of national education, where according to the National Education System Law that the purpose of national education is to develop the potential of students to become human beings who believe and fear God Almighty, have a noble character, are healthy, knowledgeable, capable, creative, independent, and become a democratic and responsible citizen (Undang-Undang Republik Indonesia Number 20 of 2003 concerning the National Education System). In the context of higher education, the goal of higher education is the production of science and technology through research (Undang-Undang Republik Indonesia Number 12 of 2012 concerning Higher Education). 
Based on the law above, it is very clear that as scientists and professional educators, lecturers are obliged to carry out the Tridharma of Higher Education, one of which is in the form of disseminating creative ideas and findings from in-depth research results. This research is an implementation of the professional competence of lecturers, which according to Hatip et al., (2018); Purwati \& Supandi (2011); Simarmata (2016) that professional lecturers are creative lecturers, who have attitudes and behaviors to increase productivity and optimize the utilization of strategic resources through research and development of science and technology in a sustainable manner. The results of this study are expected to contribute to providing problem-solving services faced by the community.

Meanwhile, the focus of the study in this study is on the financial performance of Community Health Centers (Puskesmas) which are currently carrying out institutional transformation into Regional Public Service Agency (BLUD) Public Health Centers. When becoming a BLUD Health Center, this institution is obliged to clean up and pay attention to accounting management and institutional financial management. When it became a BLUD Puskesmas, UndangUndang Republik Indonesia concerning Regional Government (2014) mandated that to provide services to the community, BLUDs must be guided by the provisions of laws and regulations and must comply with the pattern of financial management by the governance of an entity. Financial management is inseparable from the presentation of financial statements which theoretically are divided into two, namely presentations based on business accounting and public sector accounting.

According to Bastian (2013), business sector accounting (also known as private sector accounting) has the goal of seeking maximum business profits. While public sector accounting is applied to institutions that are oriented and aim to realize the welfare of the community. As part of the local government, Puskesmas also serve the community in terms of health which is based on the Regulation of the Minister of Health of the Republic of Indonesia concerning Community Health Centers (2014), that Puskesmas is a health service facility that organizes public health efforts and first-level individual health efforts by prioritizing promotive and preventive efforts, to achieve the highest degree of public health in its working area.

Meanwhile, to carry out its activities as a BLUD, it is necessary to supervise and develop BLUD Puskesmas to improve performance in carrying out basic health services and healthy business practices related to financial management to realize an independent and competitive Puskesmas. Financial management in this study is directed at achieving the financial performance of BLUD Puskesmas which is limited to three aspects, namely the current ratio, financial efficiency, and Return on Assets (ROA) (Allawiyah, 2020; Fatihudin et al., 2018a; Irman et al., 2020; Khrishnankutty \& Chakraborty, 2011; Pangestuti, 2018; Wulandari et al., 2018; Yuesti et al., 2020).

In general, accounting science is divided into two, namely: public sector accounting which is controlled by politicians and/or bureaucrats to meet public 
needs, as well as business accounting which is controlled by the private sector or companies (business entities) that have a motive for seeking maximum profit (Jones, 2014). While Bastian defines that public sector accounting as a technique, an analytical mechanism regarding accounting that is implemented on the management of funds collected from the public (Bastian, 2013). Public sector accounting is also known as government accounting, which records all transactions using state money and provides reports to assess the government's performance in finance for a certain period (Ayensu, 2018).

Then to distinguish it from business sector accounting, the scope of public sector accounting is reduced to eight aspects covering several main areas, namely: (1) central government accounting; (2) local government accounting; (3) political party accounting; (4) NGO accounting; (5) foundation accounting; (6) school and college education accounting; (7) health accounting, health centers, and hospitals; and (8) accounting for places of worship, mosques, churches, monasteries, and temples (Bastian, 2013).

Talking about Puskesmas accounting which is a special concern in this study, cannot be separated from the transformation of Puskesmas into BLUD. The birth of the BLUD Health Center is based on the Regional Government Law that regions can form BLUDs to improve services to the community by referring to the provisions of the legislation. BLUD is a system implemented by regional work units or work units in regional government work units in providing services to the public who have flexibility in financial management patterns as an exception to the provisions of regional management in general (Regulation of the Minister of Health of the Republic of Indonesia concerning Community Health Centers, 2014).

Financial performance is used to evaluate a company every period can be reviewed based on certain aspects. The aspects that are assessed in assessing financial performance can be based on aspects of liquidity, capital adequacy, profitability, efficiency, and so on. Aspects of profitability and efficiency are mutually integrated, where the more efficient an entity is, the more profitable it is. Profit is also called a surplus where this condition occurs when operating income is greater than operating costs (Fatihudin et al., 2018b). Financial performance can be assessed based on the current ratio and ROA, where the current ratio describes the ability of an entity to pay all of its current obligations based on its current assets. Meanwhile, ROA can be used to project the company's financial condition. The higher the ROA value, it can be concluded that the company is more profitable (Brigham \& Houston, 2014; Harahap, 2015; Irman et al., 2020; Syamsuddin, 2013).

Considering the current ratio, efficiency and ROA are very important to measure the success of the institution if it is reviewed based on financial aspects, this research is directed to examine these three selected financial aspects. Assessment of these three aspects is important and not only for profit-oriented companies but also relevant to be used to assess the financial performance of the 
public sectors. According to (Guță, 2012) the public sector is an activity and service organized by state organizations. Meanwhile, Jones (2014) suggests that what is meant by the public sector are non-profit sectors or organizations that are not solely profit-oriented but have obligations in terms of financial control.

The current ratio is used to measure the level of liquidity and can project profit margins over a certain period. This ratio is determined by the value of receivables, payables, inventories, and company size (Khrishnankutty \& Chakraborty, 2011). The current ratio also shows the percentage of current assets to total assets (Yuesti et al., 2020). About public sector accounting, the current ratio is a ratio that describes the ability of local governments to ensure the fulfillment of current obligations with their current assets. The higher this ratio shows that the local government has sufficient remaining current assets to ensure the fulfillment of current liabilities.

Meanwhile, to calculate the Current Ratio using a formula that takes into account two instruments, namely total current assets and total current liabilities (Brigham \& Houston, 2014; Harahap, 2015; Pangestuti, 2018; Syamsuddin, 2013) below.

Current Ratio $=\frac{\text { Total Current Assets }}{\text { Total Current Liability }} \times 100 \%$

As one of the aspects used to measure financial performance, especially related to liquidity ratios, the current ratio can be used to measure an entity in fulfilling its short-term obligations promptly so that it can be stated that the entity is "liquid" (Yuliyanto \& Hasanah, 2020). In the business world, the current ratio is a commonly used measure to present the extent to which current liabilities can be covered by current assets. If the results of the comparison of current assets and current liabilities are greater, the ability of the entity to cover its short-term obligations is also higher. Syamsuddin (2013) suggests, calculating the company's ability to pay current debts with available current assets.

Meanwhile, Vasiu et al., (2015) explained that if the current ratio is below 1, the company cannot fulfill its short-term obligations because it does not have enough liquid assets. A current ratio below 1 means the company does not have enough liquid assets to cover its short-term liabilities. This low current ratio value also reflects those current liabilities are greater than current assets and this is a warning about financial dangers in the future.

Assessment of the performance of a public sector organization is currently still focused on three concepts, namely economy, efficiency, and effectiveness (Bastian, 2013). Financial efficiency is obtained from the comparison of costs incurred by local governments (also known as expenditure realization) to obtain Regional Original Revenue with the realization of Regional Original Revenue 
(Nurhayati, 2015; Pangestuti, 2018; Tarmizi et al., 2014; Zuhri \& Soleh, 2016) as the following formula.

Financial Efficiency $=\frac{\text { Shopping Realization }}{\text { Revenue realization }} \times 100 \%$

While the criteria for the value of financial efficiency are based on the opinion of Zuhri \& Soleh (2016) that it is classified as efficient if the efficiency ratio value is less than 1 or below 100\%. Then Cicilia et al., (2019); Nurhayati (2015); Saumillaili \& Handayani (2021) grouped them into 5 criteria as shown in the following table.

Table 1. Financial Efficiency Level

\begin{tabular}{cc}
\hline Value Interval & Designation \\
\hline$<60 \%$ & Very Efficient \\
$60 \%-80 \%$ & Efficient \\
$80 \%-90 \%$ & Quite Efficient \\
$90 \%-100 \%$ & Less Efficient \\
$>100 \%$ & Not efficient \\
\hline
\end{tabular}

ROA is an important aspect that is used to measure the level of profitability of companies and local governments. The company must be in a favorable condition or profitable to carry on its life. ROA measures the level of net income obtained from the company's total assets. And the formula commonly used to calculate the ROA value is as follows (Brigham \& Houston, 2014; Harahap, 2015; Pangestuti, 2018; Sutaryo et al., 2010; Syamsuddin, 2013).

$\mathrm{ROA}=\frac{\text { Net Surplus }}{\text { Total Asset }} \times 100 \%$

Meanwhile, to decide whether or not the performance of a company or local government is based on the opinion of Winarno (2019) that the higher this ratio the better. And a company whose ROA value is higher, it can be said that the company is more effective because the increase in the number of profits is greater than the increase in assets (Almira \& Wiagustini, 2020; Wijaya, 2019). For signs, in classifying the ROA value, it is based on the opinion (Pariyanti \& Zein, 2018) as follows.

Table 2. ROA level

\begin{tabular}{cc}
\hline ROA & Criteria \\
\hline$\geq 10 \%$ & Very Effective or Very Good \\
$7 \%-<10 \%$ & Effective or Good \\
$3 \%-<7 \%$ & Effective Enough or Good Enough \\
$1 \%-<3 \%$ & Less Effective or Less Good \\
$<1 \%$ & Ineffective or Not Good \\
\hline
\end{tabular}


Khrishnankutty \& Chakraborty (2011) in their study explained that the current ratio measures liquidity and margins (company profits). However, this current ratio is very sensitive to debt. This means that the higher the level of debt, the current ratio decreases. While the study (Sholikah, 2018) that this current ratio is very relevant to be used to measure the performance of local governments.

Suyono's research (2010) aims to examine the effect of grants, taxes, capital, real estate, expenditure, and revenue on the current ratio. The current ratio is chosen to interpret the financial performance of local governments. This study was conducted in 304 districts/cities in Indonesia. With multiple regression using SPSS, it was found that the financial performance of local governments as proxied by the Current Ratio (one of them) was influenced by the amount of local government revenue. These results indicate that the greater the local government revenue, the local government has a good financial performance. And conversely, if the income is getting lower or less in each period, the financial performance of the local government will decrease, especially in providing services to the community.

The current ratio is an indicator to assess liquidity in addition to other indicators, namely the Acid Test Ratio and Net Working Capital. In particular, this current ratio is not only used to evaluate liquidity, but also to assess the company's ability to pay its short-term debt. Likewise, at the Subang District Health Center, wherein 2019 it decided to maintain its liquidity so that it could maximize its profits (Allawiyah, 2020). A high current ratio value ( $>1$ ) will facilitate the company in managing the organization financially. And vice versa if the value of the current ratio $<1$ then it can burden the company in the long term (Vasiu et al., 2015).

Allawiyah's research (2020) examines the contribution of working capital efficiency, debt levels, and liquidity to the profitability of the BLUD Health Center in Subang Regency. This study was conducted in 2019, thus the observation period is only 1 year. The results showed that to earn a profit, the Puskesmas had to manage working capital, considering that the higher the working capital, the more efficient the Puskesmas. So, the efficient use of capital is not only for business companies, even public agencies such as public accounting also need to be efficient in using their working capital to be able to develop in excellently serving the community.

Research on 37 BLUD Health Centers in DKI Jakarta 2016 shows that working capital efficiency has a significant effect on the profitability of Puskesmas. It was further explained that the more efficient the Puskesmas in using working capital, the more controlled working capital turnover would be in a certain period (Pangestuti, 2018).

Puskesmas is one of the Regional Technical Implementation Units (UPTD) which is under the coordination of the Health Office in certain Regional Governments. One of the inputs in the form of Puskesmas funding sources comes from support for other health service operational costs obtained from the 
government so that the use of funds must be efficient and accountable to the public (Pamungkas et al., 2016). Thus, when the Puskesmas has transformed into a BLUD, financial management must use public sector accounting principles.

Even the efficient use of working capital does not only occur in BLUD Puskesmas but local governments are also required to maintain financial traffic to create high-performing government institutions (Nurhayati, 2015; Tarmizi et al., 2014; Zuhri \& Soleh, 2016).

Discussions on ROA are not only related to the business sector, such as profitoriented companies, but also government agencies such as business accounting studies and public sector accounting. Wulandari et al., (2018) in their research on 15 Regency/City Regional Governments in Indonesia found that if the district/city has a high amount of surplus, then the local government has a high financial performance ratio. However, the high surplus does not necessarily indicate that the local government has sufficient funds to finance development in the next period. The surplus generated by the regional government must be returned to the state treasury and the regional government concerned is only allowed to submit a budget to the central government in the amount of the previous year's realization. For this reason, local governments that have a high surplus have a high probability of experiencing financial distress so that they are unable to provide services to the public by the minimum standards of service quality that have been set.

A study on Regional Drinking Water Companies in Central Maluku Regency by choosing ROA as a research variable shows that increasing ROA can have a positive impact on the company's financial performance because companies increasingly can invest. Increasing ROA is certainly better for the development of institutional performance (Barli, 2016; Hariyanti, 2008). However, increasing the ROA value is influenced by many variables according to the type of business at each institution (Puspitasari et al., 2020). Thus, this ROA ratio is financially used by an entity to measure its success in the form of net profit or business surplus by allocating several assets used in a certain period, namely one year.

\section{METHOD}

The approach of this research is quantitative, considering that the main data of this study uses numerical data or numbers about the financial performance of the Puskesmas in terms of the current ratio, capital efficiency, and ROA aspects. The type of research chosen is descriptive because this study only examines a single variable, namely financial performance which is photographed based on aspects of current ratio, capital efficiency, and ROA. The population of this study is the financial report of Puskesmas "X" using annual data in 2016 and 2017.

While the selected sampling technique is saturated sampling or census sampling because the research population is the same as the research sample. Therefore, this study is a population study where researchers only observe financial 
statement data for two years, namely 2016 and 2017. The data collection technique uses documentation, namely Public Health Center financial report documents published online so that it can be used by any party, especially for scientific purposes.

The source of research data uses secondary data with time-series data types. While the data analysis technique chosen is using descriptive statistics combined with a bar graph display that can explain the progress of research variables and research instruments. Where for the variable current ratio using 2 instruments, namely total current assets and total current liabilities. The financial efficiency variable also uses 2 instruments, namely the realization of expenditure and the realization of income. As for the ROA variable using research instruments, namely net income and total assets.

\section{RESULTS AND DISCUSSION}

\section{Results}

\section{Total Current Assets}

Total current assets are the sum of several account names, namely: (1) cash and cash equivalents; (2) Short term investment; (3) accounts receivable; (4) other receivables; (5) reserve for losses on receivables; (6) prepaid expenses and (7) inventories. The total current assets are available in the financial statements (balance sheet) of the Puskesmas and not all account names are available in this financial report. The name of the account for which data is available on the balance sheet of the Puskesmas in both 2016 and 2017 are cash and cash equivalents, accounts receivable, and inventories. First, cash and cash equivalents, namely the value of cash plus deposits that can be withdrawn at any time, including short-term investments with maturities of less than or equal to three months. Second, Account receivable is the sum of general patient receivables, BPJS patient receivables, Jamkesda receivables, company guarantee receivables, independent Aske's patient receivables, Jamkesmata receivables, and other insurance receivables. Based on the observations of researchers, the data available in 2016 and 2017 is data on BPJS patient receivables.

Third, inventories that can be traced from the inventory value of pharmaceutical materials include several account names, namely supplies for pharmaceutical drugs, medical consumables, medical devices, radiology, radiotherapy, laboratories, cleaning materials, and food items. However, the inventory whose data is available in the inventory finance post is only the name of the consumable medical supplies account. The total current asset value of the Puskesmas in 2016 and 2017 increased by Rp 508,548,440 as shown in the image below. 


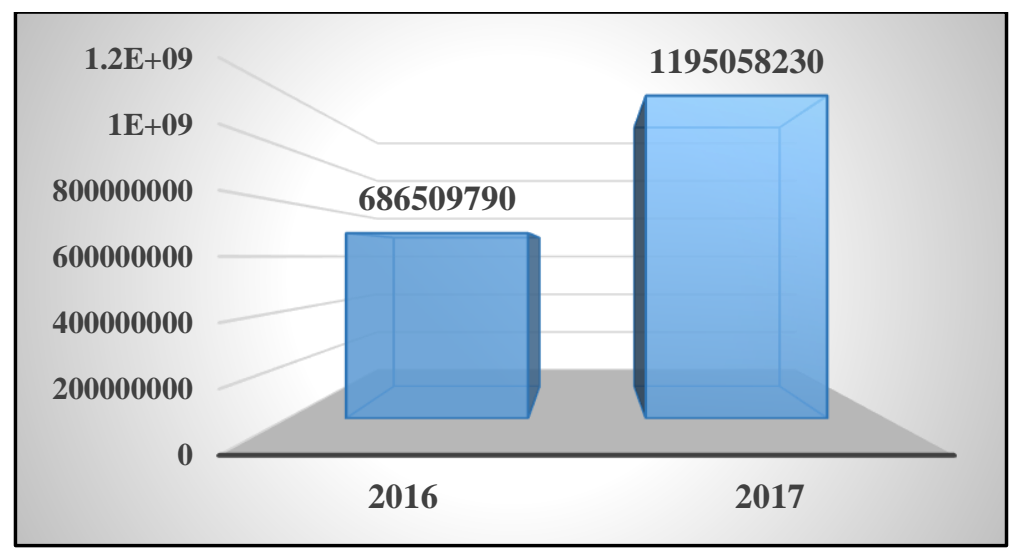

Figure 1. Total Current Assets

\section{Total Current Liability}

Debt is a company obligation that arises because of past actions or transactions to obtain assets or services, the repayment of which will only be made in the future, either by delivering cash, certain other assets, services or by creating new debt. Debt can give rise to financial obligations or performance obligations. For example, financial obligations such as trade payables, taxes payable, dividends payable, interest payable, and so on, while performance obligations, such as rent received in advance, expenses received in advance, purchase guarantee money from buyers (Nuswantara, 2003).

Meanwhile, total current liabilities, also known as total short-term liabilities, are obligations or debts that must be paid/paid/fulfilled by the debtor within the accounting period, usually one year. Based on the researcher's observations of the Puskesmas balance sheet documentation, it can be stated that the total current liabilities are the accumulation of several items, namely: trade payables, interest payable, current portion of long-term debt, interest payable, taxes payable, accrued expenses and income received in advance. However, the available data regarding total current liabilities are only accrued costs in the amount of Rp. 173,786,264 (in 2016) and Rp. 88,186,264 (in 2017). So, it can be concluded that the costs to be paid are none other than the total current liabilities decreased by Rp. 85.600 .000 (see Figure 2). 


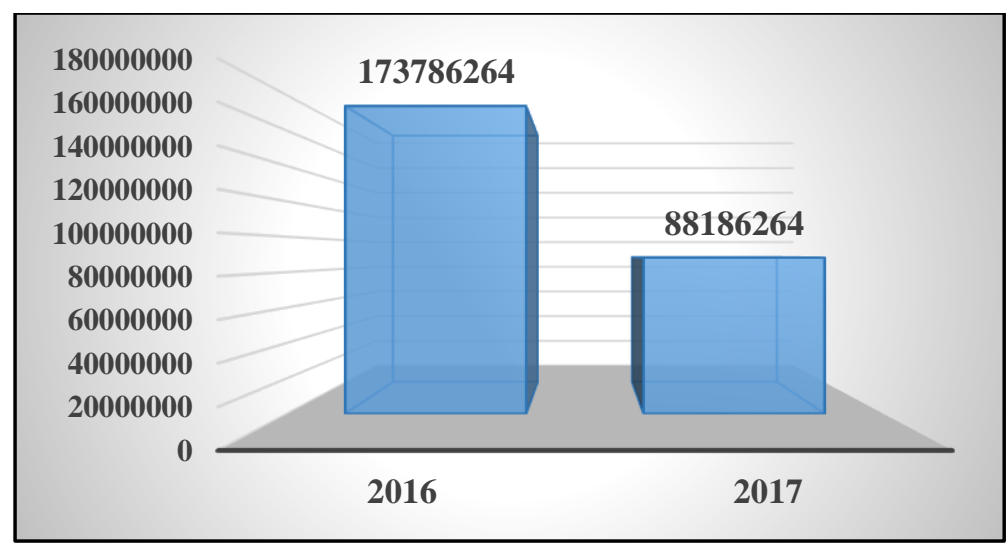

Figure 2. Total Current Liability

\section{Current Ratio}

The Current Ratio or current ratio is calculated from the comparison of total current assets and total current liabilities. Based on the calculation results, it is known that the current ratio of the Puskesmas has increased from 3.95\% in 2016 to 13.55\% in 2017 (see Figure 3). This increase in the current ratio can be explained that the current assets of the Puskesmas can cover current liabilities. The greater the ratio of current assets to current liabilities, the higher the ability of the Puskesmas to cover its short-term obligations in the form of trade payables, interest payable, current portion of long-term debt, interest payable, taxes payable, accrued expenses, and unearned income.

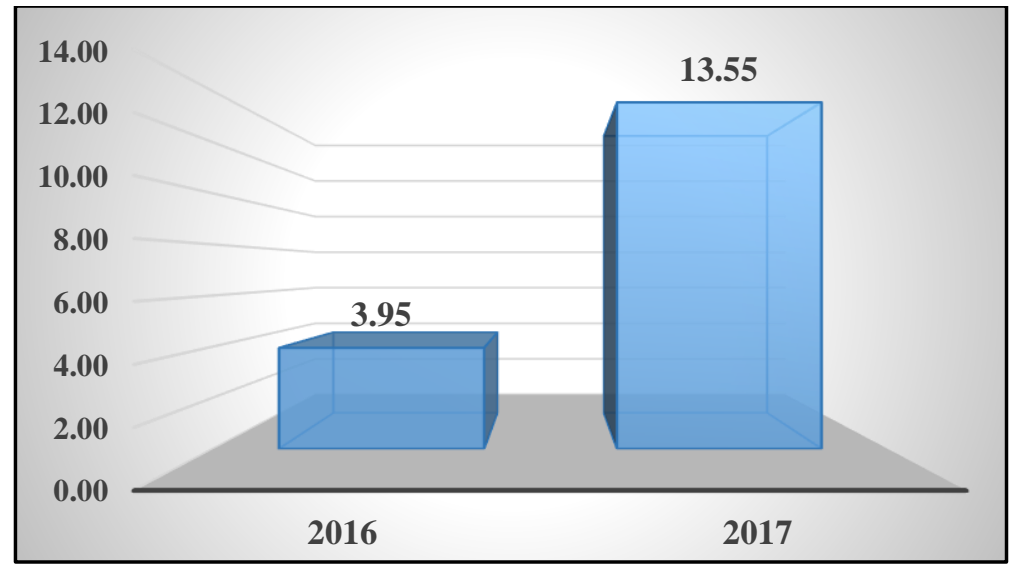

Figure 3. Current Ratio

\section{Financial Efficiency}

Theoretically, financial efficiency is calculated based on a comparison of the realization of expenditure with the realization of income. Specifically related to the realization of spending comes from service costs plus administrative and general costs. According to the Puskesmas documentation, these two account names (realized expenditure and realized income) are only available in 2017, and data in 
2016 is not available. So, the study of financial efficiency is only in 2017. Figure 4 is a map of the realization of expenditure and realization of income, where the value of realized expenditure is smaller than the realization of income. And if it is calculated, the value of the Puskesmas financial efficiency is $74 \%$ which is obtained from the comparison of the realization of overspending (Rp 1,779,459,183) with the realization of income $(\operatorname{Rp} 2,409,214,823)$. Thus, the level of financial efficiency of the Puskesmas is in an efficient position if it is based on table 1.

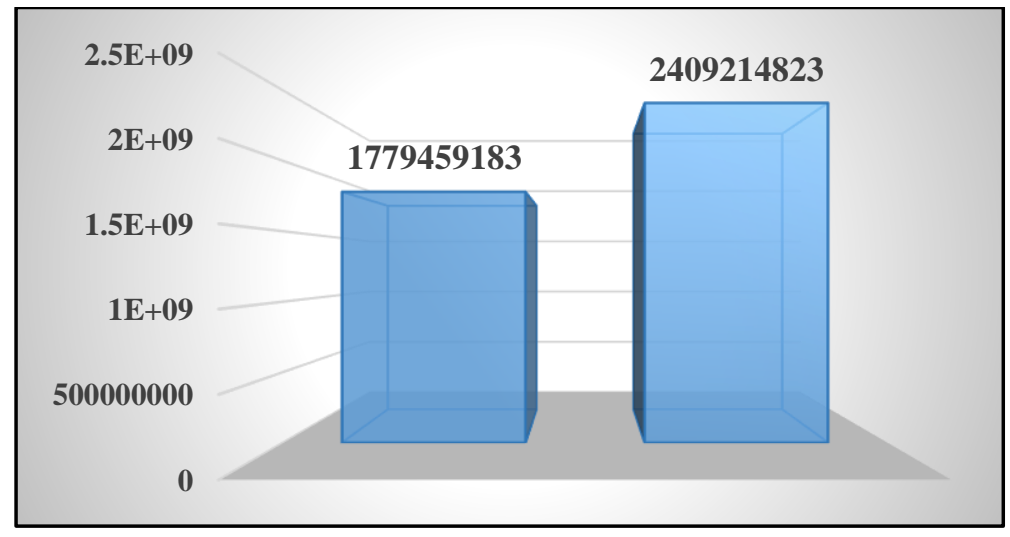

Figure 4. Financial Efficiency

\section{ROA}

This ratio describes asset turnover as measured by net surplus. The bigger this ratio, the better, this means that assets can be turned around more quickly to make a profit or if in the Puskesmas it is called a net surplus. Based on observations of the data published by the Puskesmas, it can be calculated that the ROA in 2017 was 0.029426798 or $3 \%$. If it is associated with table 2 , it can be concluded that the ROA level of the Puskesmas is in the criteria of Quite Effective or Good Enough because it is in the range of $3 \%-<7 \% .2016$ is not counted in this study because data on net income or net surplus are not available.

\section{Discussion}

If viewed from the aspect of the current ratio, the results of this study are relevant to previous research, because the current ratio value of the Puskesmas has increased from 2016 to 2017. This increase makes the Puskesmas have a good financial performance during the research period. Previous researchers are Khrishnankutty \& Chakraborty (2011); Sholikah (2018); Allawiyah (2020) and Vasiu et al., (2015) stated that the larger the current ratio, the better the financial performance of the Puskesmas so that the results of this study support the findings of previous researchers. These results are also relevant to the theories proposed by Bastian (2013); Brigham \& Houston (2014); Harahap (2015); Syamsuddin (2013). 
Based on the research findings on financial efficiency, the Puskesmas in the research period was in the efficient criteria. This is because expenditures are smaller than the realization of revenues so that their financial position becomes efficient. This is what makes the Puskesmas financially stronger so that the transformation into a BLUD Puskesmas can be felt, both institutionally and personally, by Puskesmas employees. This study is relevant to the theory proposed by Brigham \& Houston (2014); Harahap (2015); Syamsuddin (2013), and supports the findings of Allawiyah (2020); Pangestuti (2018); Pamungkas et al., (2016); Nurhayati (2015); Tarmizi et al., (2014); Zuhri \& Soleh (2016).

Likewise, with ROA, the Puskesmas in 2017 was able to present itself as a Health Center that was Effective Enough or Good Enough in managing asset turnover to obtain a net surplus. Although not yet in a very effective or very good position, this puskesmas is empirically proven to have financial performance that needs to be maintained and even improved in the future. The results of this study support the theory proposed by Brigham \& Houston (2014); Harahap (2015); Syamsuddin (2013), as well as relevant to the research of Wulandari et al., (2018); Barli (2016); Hariyanti (2008); Puspitasari et al., (2020).

\section{CONCLUSION}

Lecturer's professional competence is an integral part of classroom learning management. The form of this learning management is an assessment of financial ratios and selected health centers which are expected to provide a quantitative picture to students about the financial performance portrait of the health center. Based on the current ratio, Puskesmas need to pay attention to the ratio between total current assets and total current liabilities so that the results are increasing from year to year. Likewise with financial efficiency, although Puskesmas receive financial support from the government, strict management regarding expenditure realization and revenue realization must be a special concern to become an efficient institution. Meanwhile, in terms of ROA, Puskesmas should not be negligent about total asset management. Because it is proven that the total assets financially contribute to the net surplus of the Puskesmas, so that to become an effective institution and even become very effective or very good, it is necessary to manage current assets, fixed assets, and other assets as an integral part of the total assets of the Puskesmas.

\section{REFERENCES}

Allawiyah, F. Z. (2020). Pengaruh Likuiditas, Tingkat Utang, Efesiensi Modal Kerja Terhadap Kemampuan Laba Pada Badan Layanan Umum Daerah (BLUD) Puskesmas Kab. Subang Tahun 2019. PRISMA (Platform Riset Mahasiswa Akuntansi), 01(05), $12-21$. https://doi.org/https://ojs.stiesa.ac.id/index.php/prisma 
Almira, N. P. A. K., \& Wiagustini, N. L. P. (2020). Return on Asset, Return on Equity, dan Earning Per Share Berpengaruh Terhadap Return Saham. E-Jurnal Manajemen Universitas

Udayana. https://doi.org/10.24843/ejmunud.2020.v09.i03.p13

Ayensu, F. (2018). Public Sector Accounting. For Icag Exams, Business Students ETC. https://www.researchgate.net/publication/325381307_Public_Sector_Accou nting

Barli, H. (2016). Analisis Pengaruh Return on Assets, Pertumbuhan Laba dan Leverage terhadap Return Saham. Jurnal Ilmiah Akuntansi Universitas Pamulang, $4(1)$, 832-858. https://doi.org/http://dx.doi.org/10.32493/jiaup.v4i1.150

Bastian, I. (2013). Akuntansi Sektor Publik Suatu Pengantar. In Jakarta: Erlangga. Brigham, E. F., \& Houston, J. F. (2014). Dasar-Dasar Manajemen Keuangan Edisi 11 Buku 1. In Salemba Empat Jakarta.

Cicilia, V. S. E., Murni, S., \& Engka, D. (2019). Analisis Efisiensi dan Efektivitas Serta Kemandirian Pengelolaan Keuangan Daerah di Kabupaten Minahasa Utara. Jurnal Pembangunan Ekonomi Dan Keuangan Daerah. https://doi.org/10.35794/jpekd.10245.17.2.2015

Fatihudin, D., Jusni, \& Mochklas, M. (2018a). How measuring financial performance. International Journal of Civil Engineering and Technology, 9(6), 553-557. https://www.researchgate.net/publication/326141100_How_Measuring_Fin ancial_Performance

Fatihudin, D., Jusni, \& Mochklas, M. (2018b). How measuring financial performance. International Journal of Civil Engineering and Technology.

Guţă, A. J. (2012). Characteristics of Public Sector Management. Annals of the University of Petroşani, Economics, 12(4), 95-102. https://core.ac.uk/download/pdf/26741748.pdf

Harahap, S. S. (2015). Analisis Kritis atas Laporan Keuangan. PT Raja Grafindo Persada.

Hariyanti, D. (2008). Analisis Pengaruh Return On Assets dan Beban Pajak Terhadap Struktur Keuangan pada Perusahaan Daerah Air Minum Kabupaten Maluku Tengah. Jurnal Ekonomi MODERNISASI, 4(3), 175-184. https://doi.org/10.21067/jem.v4i3.238

Hatip, M., K, K., Sanosra, A., \& Qomariah, N. (2018). Kompetensi Dosen, Profesionalisme Dosen, dan Kecerdasan Spritual Dampaknya terhadap Motivasi Belajar Mahasiswa. Jurnal Sains Manajemen dan Bisnis Indonesia. https://doi.org/10.32528/smbi.v8i1.1770

Irman, M., Purwati, A. A., \& Juliyanti. (2020). Analysis On The Influence Of Current Ratio, Debt to Equity Ratio and Total Asset Turnover Toward Return On Assets On The Otomotive and Component Company That Has Been Registered In Indonesia Stock Exchange Within 2011-2017. International Journal of 
Economics Development Research (IJEDR), 1(1), 36-44. https://doi.org/10.37385/ijedr.v1i1.26

Jones, R. (2014). Public Sector Accounting. In Public Sector Accounting. https://doi.org/10.4135/9781446263105

Khrishnankutty, R., \& Chakraborty, K. . (2011). Determinant of Current Ratios: A Study Wth Refereence to Companies Listed in Bombay Stock Exchange. In Munich Personal RePEC Archive. https://www.researchgate.net/publication/239809851_Determinants_of_Cu rrent_Ratios_A_Study_with_Reference_to_Companies_Listed_in_Bombay_Stock _Exchange

Nurhayati. (2015). Analisis Rasio Keuangan Untuk Mengukur Kinerja Pemerintah Daerah Kabupaten Rokan Hulu. Jurnal Ilmiah Cano Ekonomos.

Nuswantara, D. A. (2003). Mengerjakan Prosedur Akuntansi Hutang Jangka Pendek \& Panjang. Bagian Proyek Pengembangan Kurikulum Direktorat Pendidikan Menengah Kejuruan Direktorat Jenderal Pendidikan Dasar Dan Menengah Departemen Pendidikan Nasional.

Pamungkas, B. D., . W., \& Firmansyah, M. (2016). Analisis Efisiensi Puskesmas di Kabupaten Sumbawa Tahun 2015. Jurnal Ekonomi Dan Ekonomi Studi Pembangunan. https://doi.org/10.17977/um002v8i22016p183

Pangestuti, D. C. (2018). Determinan Kemampuan Laba Pada Badan Layanan Umum Daerah (BLUD) Puskesmas Kecamatan Pemerintah Provinsi DKI Jakarta Tahun 2016. Jurnal Perilaku Dan Strategi Bisnis, 6(2), 147. https://doi.org/10.26486/jpsb.v6i2.566

Pariyanti, E., \& Zein, R. (2018). Analisis Kinerja Keuangan pada Koperasi Simpan Pinjam dan Pembiayaan Syariah BMT Sepadan Kecamatan Pasir Sakti Lampung Timur. Fidusia: Jurnal Keuangan Dan Perbankan. https://doi.org/10.24127/jf.v1i2.303

Regulation of the Minister of Health of the Republic of Indonesia No. 75 of 2014 concerning Community Health Centers

Purwati, H., \& Supandi. (2011). Meningkatkan Kompetensi Dan Profesionalisme Dosen Melalui Lesson Study. Aksioma.

Puspitasari, L., Sulindawati, N., \& Sujana, E. (2020). Pengaruh Rasio Keuangan Terhadap Return On Assets Pada Bank Pembangunan Daerah di Seluruh Indonesia Tahun 2015-2019. JIMAT (Jurnal Ilmiah Mahasiswa Akuntansi), 11(2), $13-21$. https://ejournal.undiksha.ac.id/index.php/S1ak/article/view/24954

Saumillaili, D. R., \& Handayani, N. (2021). Analisis Komparatif Kinerja Puskesmas Pangarengan dan Puskesmas Kedungdung dengan Menggunakan Metode Balanced Scorecard. Jurnal Ilmu Dan Riset Akuntansi, 10(4), 1-19.

Sholikah, M. (2018). Analisis Rasio Untuk Mengukur Kinerja Pengelolaan Keuangan Kota Surabaya. In Skripsi Fakultas Ekonomi Universitas 17 agustus 1945 
Volume 5 Number 1 September 2021

Surabaya.

Simarmata, J. (2016). Karakterisistik Dosen Profesional Menurut Mahasiswa:

Sebuah Survey Di FKIP Universitas Batanghari. Jurnal Ilmiah Dikdaya.

Sutaryo, Sutopo, B., \& Setyawan, D. (2010). Bambang sutopo. Simposium Nasional

Akuntansi XIII Purwokerto 2010, 1-31.

https://sutaryofe.staff.uns.ac.id/files/2011/10/SNA13-PURWOKERTO.pdf

Suyono. (2010). Analisis Kinerja Keuangan Pemerintah Daerah di indonesia. Jurnal

$\begin{array}{llll}\text { Akuntansi Dan } & \text { Bisnis, }\end{array}$

https://doi.org/http://dx.doi.org/10.20961/jab.v10i2.116

Syamsuddin, L. (2013). Manajemen Keuangan Perusahaan. Jakarta: Raja Grafindo Persada.

Tarmizi, R., Khairudin, K., \& Jayadi, A. (2014). Analisis Kinerja Keuangan Pemerintah

Daerah Kota Bandar Lampung Sebelum Dan Setelah Memperoleh Opini WTP.

Jurnal Akuntansi Dan Keuangan. https://doi.org/10.36448/jak.v5i2.546

Undang-Undang Republik Indonesia Number 12 of 2012 concerning Higher

Education.

Undang-Undang Republik Indonesia Number 20 of 2003 concerning the National

Education System

Undang-Undang Republik Indonesia Number 23 of 2014 concerning Regional Government

Vasiu, D. E., Balteș, N., \& Gheorghe, I. N. (2015). Liquidity ratios . A structural and dynamic analysis, during 2006-2012, of the companies having the business line in industry and construction, listed and traded on the Bucharest Stock Exchange. Theoretical and Applied Economics, XXII(3), 187-206.

Wijaya, R. (2019). Analisis Perkembangan Return On Assets (ROA) dan Return On Equity (ROE) untuk Mengukur Kinerja Keuangan. Jurnal Ilmu Manajemen. https://doi.org/10.32502/jimn.v9i1.2115

Winarno, S. H. (2019). Analisis NPM, ROA, dan ROE dalam Mengukur Kinerja Keuangan. Jurnal STEI Ekonomi. https://doi.org/10.36406/jemi.v28i02.254

Wulandari, I., Nugraeni, N., \& Wafa, Z. (2018). Faktor-Faktor yang Mempengaruhi Financial Distress Pemerintah Daerah. Jurnal Riset Akuntansi Mercu Buana. https://doi.org/10.26486/jramb.v4i2.639

Yuesti, A., Dewi, L. P. ., \& Pramesti, I. G. A. . (2020). Akuntansi Sektor Publik. In Riset Akuntansi dan Keuangan Indonesia (Vol. 17, Issue Juni). CV. Noah Aletheia.

Yuliyanto, W., \& Hasanah, U. (2020). Analisis Laporan Keuangan Terhadap Kinerja Keuangan KP-RI XYZ Periode 2015-2018. Jurnal E-Bis (Ekonomi-Bisnis). https://doi.org/10.37339/e-bis.v3i2.209

Zuhri, M., \& Soleh, A. (2016). Analisis Kinerja Keuangan Pemerintah Daerah Kabupaten Kaur. Ekombis Review: Jurnal Ilmiah Ekonomi Dan Bisnis. https://doi.org/10.37676/ekombis.v4i2.284 